\title{
The Effect of Phase on Paper Thickness Optimization in the Recycling Process Using Recycling Machine
}

\author{
Fauzhia Rahmasari ${ }^{1}$ \\ ${ }^{1}$ Department of Industrial Technology, Jayabaya University. Jl. Raya Bogor Km. 28,8 Cimanggis, Jakarta \\ Timur, Indonesia \\ Coressponding Author. E-mail: \\ fauzhiarahmasari@gmail.com
}

Received: December 16 $16^{\text {th }}, 2019$

Accepted: January 28 $8^{\text {th }}, 2020$ Online Published: January 31 st 2020

\begin{abstract}
Efforts to manage the recycling of paper waste into new paper have been carried out in recent times. It takes a tool or machine that is able to effectively and efficiently recycle used paper into new paper. There are several factors that affect the effectiveness of paper recycling machines, one of which is the paper thickness. One method that can be used to analyze the factors that influence paper thickness in the paper production process using a paper recycling machine is regression analysis. Regression analysis is data analysis techniques in statistics that is used to examine the relationship between several independent variables and dependent variable. However, if we want to examine the relationship or effect of two or more independent variables on a dependent variable, the regression model used is a multiple linear regression model. This study purposes are to analyze the factors that influence paper thickness using a paper recycling machine using multiple linear regression and to inform the modeling about that. The results showed that the factors that affect the paper thickness optimization are destruction and press phase.
\end{abstract}

Kata Kunci:: Multiple linear regression analysis; Paper making phase; Paper recycling machine; Paper thickness

\begin{abstract}
Upaya pengelolaan daur ulang sampah kertas menjadi kertas baru telah banyak dilakukan pada jaman sekarang. Dibutuhkan suatu alat atau mesin yang mampu secara efektif dan efisien dalam mendaur ulang kertas bekas menjadi kertas baru. Terdapat beberapa faktor yang mempengaruhi tingkat efektifitas mesin daur ulang kertas diantaranya adalah ketebalan kertas. Salah satu metode yang dapat digunakan untuk menganalisis faktor-faktor yang mempengaruhi ketebalan kertas pada proses produksi kertas menggunakan mesin daur ulang kertas adalah analisis regresi. Analisis regresi merupakan teknik analisis data dalam statistika yang digunakan untuk mengkaji hubungan antara beberapa variabel bebas dengan variabel tidak bebas. Namun, jika ingin mengkaji hubungan atau pengaruh dua atau lebih variabel bebas terhadap satu variabel tidak bebas, maka model regresi yang digunakan adalah model regresi linier berganda. Tujuan dalam penelitian ini yaitu menganalisis faktor-faktor yang mempengaruhi ketebalan kertas menggunakan mesin daur ulang kertas menggunakan regresi linier berganda serta memberikan informasi pemodelan mengenai hal tersebut. Hasil penelitian menunjukkan bahwa faktor yang mempengaruhi keoptimalan ketebalan kertas adalah fase penghancuran dan pemadatan kertas
\end{abstract}

Keywords: Analisis regresi linier berganda; Fase pembuatan kertas; Ketebalan kertas; Mesin daur ulang kertas

\section{How to cite this article :}

Rahmasari, F. (2020). The Effect of Phase on Paper Thickness Optimization in the Paper Recycling Process Using Recycling Machine. IJIS Edu : Indonesian Journal of Integrated Science Education, 2(1), 19-27. doi:http://dx.doi.org/10.29300/ijisedu.v2i1.2564 


\section{INTRODUCTION}

Manufacturing companies are companies engaged in processing raw materials by spending other costs into finished goods that are ready for sale. Manufacturing companies throughout the world are affected by globalization and are forced to become more competitive every day to maintain their profitability (Goddard, Tavakoli, \& Wilson, 2005; Rahmasari, 2017). Some manufacturing companies are engaged in processing waste that no longer has the benefit of being a recycled product so that it can be reused and useful for life.

Lack of awareness from humans results in a lot of littering. It can cause some pollution. However, all can be overcome if we are creative in utilizing the garbage. Besides being able to preserve the environment, it can also increase our income. One of the waste utilization techniques is recycling by making various kinds of crafts and new products (Kementerian Keuangan Republik Indonesia, 2019).

The type of waste that is commonly found is paper waste. Paper waste as wasted goods can be used by recycling into unique and artistic paper or even becoming new paper for reuse. Through paper recycling, in addition to dealing with environmental problems, can also be used as an alternative in creating new job fields (Asmatulu \& Asmatulu, 2011; Yafie, Kustiawan, \& Seken, 2018; Zahra \& Damanhuri, 2011). Efforts to manage the recycling of paper waste into new paper have been carried out in recent times. It takes a tool or machine that is able to effectively and efficiently recycle used paper into new paper. There are several factors that affect the effectiveness of paper recycling machines, one of which is the paper thickness. Therefore, it is necessary to do research on what factors influence the thickness of the paper in order to create optimal results in the production of paper on a paper recycling machine (Faraz, Biermann, \& Weinert, 2009). One method that can be used to analyze the factors that influence paper thickness in the paper production process using a paper recycling machine is regression analysis.

Regression analysis is data analysis techniques in statistics that is used to examine the relationship between several independent variables and dependent variable (Effendi, Mursilah, \& Mujiono, 2018; Widiyawati \& Setiawan, 2015). If we want to examine the relationship or effect of one independent variable, the regression model used is a simple linear regression model. However, if we want to examine the relationship or effect of two or more independent variables on a dependent variable, the regression model used is a multiple linear regression model. Then to get a simple linear regression model and multiple linear regression models can be obtained by estimating its parameters using certain methods. The methods that can be used to estimate the parameters of a simple linear regression model or multiple linear regression model is ordinary least square (OLS) and maximum likelihood estimation (MLE) (Kutner, Nachtsheim, Neter, \& Li, 2005).

This study purposes are to analyze the factors that influence paper thickness using a paper recycling machine using multiple linear regression and to inform the modeling about it to get the optimal paper thickness.

\section{METHODOLOGY}

\section{Data Sources and Research Variables}

In this study, the data used are secondary data obtained from the result of the study whose the observations were made in recycle paper mills. The data obtained are as follows:

Table 1. Observational data

\begin{tabular}{cccccccc}
\hline No & $Y$ & $x_{1}$ & $x_{2}$ & $x_{3}$ & $x_{4}$ & $x_{5}$ & $x_{6}$ \\
\hline 1 & 43 & 51 & 30 & 39 & 61 & 92 & 45 \\
2 & 63 & 64 & 51 & 54 & 63 & 73 & 47 \\
3 & 71 & 70 & 68 & 69 & 76 & 86 & 48 \\
4 & 61 & 63 & 45 & 47 & 54 & 84 & 35 \\
5 & 81 & 78 & 56 & 66 & 71 & 83 & 47 \\
6 & 43 & 55 & 49 & 44 & 54 & 49 & 34 \\
7 & 58 & 67 & 42 & 56 & 66 & 68 & 35 \\
8 & 71 & 75 & 50 & 55 & 70 & 66 & 41 \\
9 & 72 & 82 & 72 & 67 & 71 & 83 & 31 \\
10 & 67 & 61 & 45 & 47 & 62 & 80 & 41 \\
11 & 64 & 53 & 53 & 58 & 58 & 67 & 34 \\
12 & 67 & 60 & 47 & 39 & 59 & 74 & 41 \\
13 & 69 & 62 & 57 & 42 & 55 & 63 & 25 \\
14 & 68 & 83 & 83 & 45 & 59 & 77 & 35 \\
15 & 77 & 77 & 54 & 72 & 79 & 77 & 46 \\
16 & 81 & 90 & 50 & 72 & 60 & 54 & 36 \\
17 & 74 & 85 & 64 & 69 & 79 & 79 & 63 \\
18 & 65 & 60 & 65 & 75 & 55 & 80 & 60 \\
19 & 65 & 70 & 46 & 57 & 75 & 85 & 46 \\
20 & 50 & 58 & 68 & 54 & 64 & 78 & 52 \\
21 & 50 & 40 & 33 & 34 & 43 & 64 & 33
\end{tabular}

http://ejournal.iainbengkulu.ac.id/index.php/ijisedu 


\begin{tabular}{llllllll}
22 & 64 & 61 & 52 & 62 & 66 & 80 & 41 \\
23 & 53 & 66 & 52 & 50 & 63 & 80 & 37 \\
24 & 40 & 37 & 42 & 58 & 50 & 57 & 49 \\
25 & 63 & 54 & 42 & 48 & 66 & 75 & 33 \\
26 & 66 & 77 & 66 & 63 & 88 & 76 & 72 \\
27 & 78 & 75 & 58 & 74 & 80 & 78 & 49 \\
28 & 48 & 57 & 44 & 45 & 51 & 83 & 38 \\
29 & 85 & 85 & 71 & 71 & 77 & 74 & 55 \\
30 & 82 & 82 & 39 & 59 & 64 & 78 & 39 \\
\hline
\end{tabular}

The variables used in the papermaking process are as follows:

The dependent variable used in this study is:

Y: Thickness $(\mu \mathrm{m})$

The independent variables used in this study are control factors, as follows (Djami, 2014):

$x_{1}$ : phase 1 , destruction part

$x_{2}$ : phase 2 , wire part

$x_{3}$ : phase 3 , press part

$x_{4}$ : phase 4 , drying part

$x_{5}$ : phase 5 , callender part

$x_{6}$ : phase 6 , heating water part

\section{Research Methods}

1. Multiple Linear Regression

The general form of multiple linear regression model with $p$-independent variable as in the following equation Johnson \& Bhattacharyya, 2010).

$$
\begin{gathered}
Y_{i}=\beta_{0}+\beta_{1} X_{i 1}+\beta_{2} X_{i 2}+\cdots \\
+\beta_{p-1} X_{i p-1}+\varepsilon_{i}
\end{gathered}
$$

with:

$Y_{i}$ is dependent variable for $i$-obervations, $i=$ $1,2, \ldots, n$.

$\beta_{0}, \beta_{1}, \beta_{2}, \ldots, \beta_{p-1}$ are the parameters.

$X_{i 1}, X_{i 2}, \ldots, X_{i p-1}$ are the independent variables.

$\varepsilon_{i}$ are the error for $i$-obervationsthat are assumed to be normally distributed that are independent and identical with the average of 0 (zero) and $\sigma^{2}$ variance.

Table 2. Analysis of Variance (ANOVA) (Irianto,

\begin{tabular}{ccccc}
\multicolumn{5}{c}{$2004)$} \\
\hline Sources & $\begin{array}{c}\text { Independen } \\
\mathrm{t} \text { Level }\end{array}$ & $\begin{array}{c}\text { Sum } \\
\text { Square }\end{array}$ & Mean Square & $F_{\text {count }}$ \\
\hline $\begin{array}{c}\text { Regress } \\
\text { ion }\end{array}$ & $p$ & SSR & $\frac{S S R}{k}$ & $\frac{M S R}{M S E}$ \\
\hline $\begin{array}{c}\text { Error } \\
\text { Residua } \\
\text { ls }\end{array}$ & $n-p-1$ & SSE & $\frac{S S E}{(n-k-1)}$ & \\
\hline Total & $n-1$ & SST & & \\
\hline
\end{tabular}

2. Model Parameter Test

a. Simultaneous test

Simultaneous test is carried out to determine the significance of the model coefficient (Kusuma \& Puspita, 2016).

- Hypothesis:

$H_{0}: \beta_{1}=\beta_{2}=\cdots=\beta_{p-1}=0$

$H_{1}$ : not all $\beta_{k}=0, k=1,2, \ldots, p-1$

- Testing statistics:

$$
F_{\text {count }}=\frac{M S R}{M S E}
$$

with:

$M S R$ is average of regression square.

$M S E$ is average of error square.

- Rejection criteria:

Reject: $H_{0}$ if $F_{\text {count }}>F_{\text {table }} ; F_{\text {table }}=$

$F_{(1-\alpha ; p-1, n-p)}$

b. Partial test

Partial test is used to see the effect of each predictor variable (Kusuma \& Puspita, 2016).

- Hypothesis:

$$
\begin{gathered}
H_{0}: \beta_{k}=0 \\
H_{1}: \beta_{k} \neq 0, k=1,2, \ldots, p-1
\end{gathered}
$$

- Testing statistics:

$$
t_{\text {count }}=\frac{\beta_{k}}{s\left(\beta_{k}\right)}
$$

with:

$\beta_{k}$ is parameter estimated value.

$s\left(\beta_{k}\right)$ is deviation standard of $\beta_{k}$.

- Rejection criteria:

Reject: $H_{0}$ if $t_{\text {count }}>t_{\text {table }}$ ort $t_{\text {count }}<$ $-t_{\text {table }} ; t_{\text {table }}=t_{\left(\frac{\alpha}{2} ; n-p\right)}$

c. Determination Coefficient $\left(R^{2}\right)$

Determination coefficient used to measure the goodness of the model. The model is said to be good if $R^{2}$ value is close to 1 (Soejanto, 2009). The formula used is:

$$
R^{2}=\frac{S S R}{S S T} \times 100 \%
$$

3. Error Assumption Test

a. Error normality test

The testing of normal error assumption is carried out using Kolmogorov-Smimov test (SATHEESH \& EDWIN RAJA DHAS, 2013) .

- Hypothesis:

$H_{0}$ : error spread normally. 
$H_{1}$ : error does not spread normally.

- Rejection criteria:

Reject: $H_{0}$ if P-value $>0,05$ at the real level $5 \%$.

b. Homogeneity test

The homogeneity test is using Glejser test (Setiawan \& Kusrini, 2010).

- Hypothesis:

$H_{0}$ : homogeneous error variance.

$H_{1}$ : heterogeneous error variance.

- Rejection criteria:

Reject: $H_{0}$ if P-value $>0,05$ at the real level $5 \%$.

c. Detect of error independencies

The test used is Runs Test (Montgomery et al., 2012).

- Hypothesis:

$H_{0}$ : independent mutual error.

$H_{1}$ : dependent mutual error.

- Rejection criteria:

Reject: $H_{0}$ if P-value> 0,05 at the real level $5 \%$.

d. Detect of multicollinearity

Multicollinearity detection for $i$ explanatory variables can use VIF test (Montgomery, Peck, \& Vining, 2012), with the formula is:

$$
V I F=\frac{1}{1-R_{i}^{2}}
$$

- Hypothesis:

$H_{0}$ : there is no multicollinarity between independent variables $(V I F<10)$.

$H_{1}$ : there is multicollinarity between independent variables $(V I F>10)$.

- Rejection criteria:

Reject: $H_{0}$ if $V I F>10$.

\section{RESULTS AND DISCUSSIONS}

Data Exploration

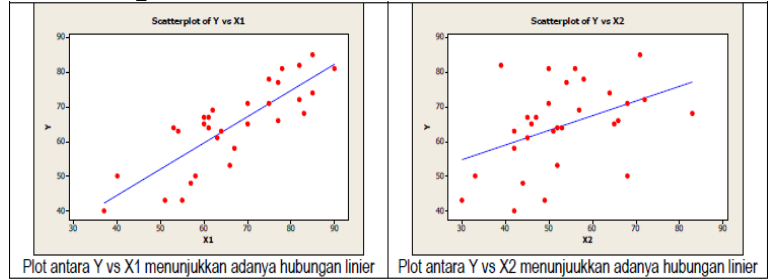

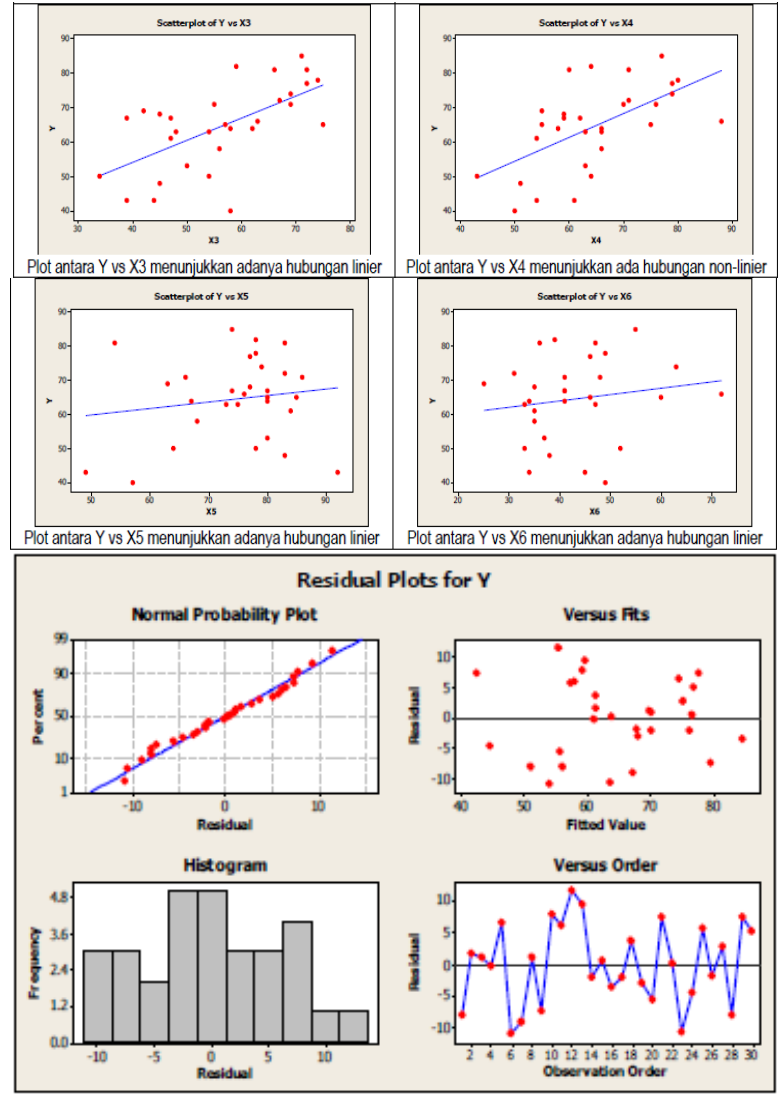

Figure 1. Results of data exploration

The normal QQ plot shows a normal spread error, this is seen from the points that are around the line. Error plot vs fitted value shows a homogeneous errors range, it can be seen from the absence of patterns formed and the same bandwidth. Error plot vs order shown no pattern, so it can be concluded that the errors are mutually independent.

\section{Result of Multiple Regression Analysis}

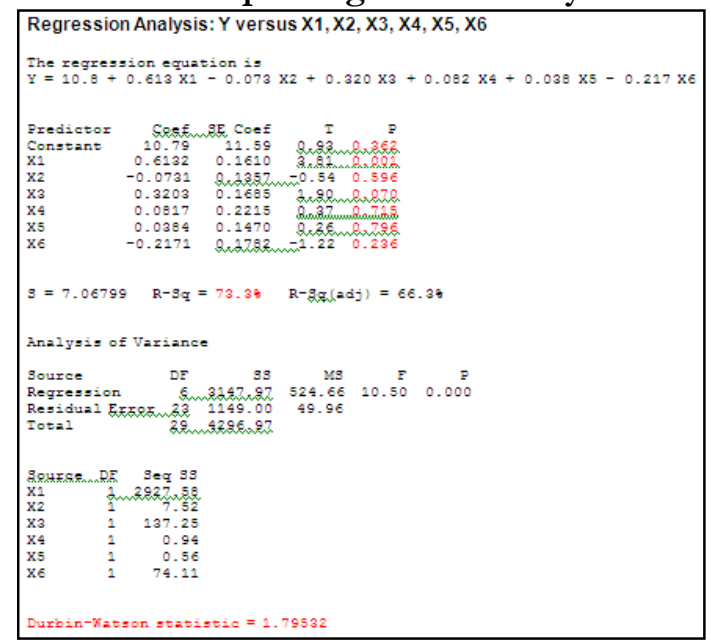

Figure 2. Result of Regression Analysis 


\section{Interpretation:}

The results of regression analysis for $Y$ with $x_{1}$ to $x_{6}$ produced significant $\mathrm{F}$ test $(\mathrm{P}$-value $<0.05)$, so there is sufficient evidence to state that there is at least one explanatory variable affecting $Y$. The t-test on each explanatory variable concluded that the $x_{1}$ and $x_{6}$ had P-value $<0.05$, it means that there is sufficient evidence to state that both variables affect $Y$ at the real level 5\%, while the other explanatory variables do not affecting $Y$. The result of $R^{2}$ value is $73.3 \%$, it means that the variance of $Y$ that can be explained by $x_{1}$ to $x_{6}$ is $73.3 \%$, while the remaining $26.7 \%$ is explained by variables outside the model. This $R^{2}$ value is relatively small, so it can be concluded if the model formed is not good enough, this is also supported by the $R^{2}$ pred value $=54.7 \%$ which is relatively low. From this regression analysis, no outliers or observations were found to be influential.

\section{Results of Error Assumption Test}

\section{Result of error normality test}

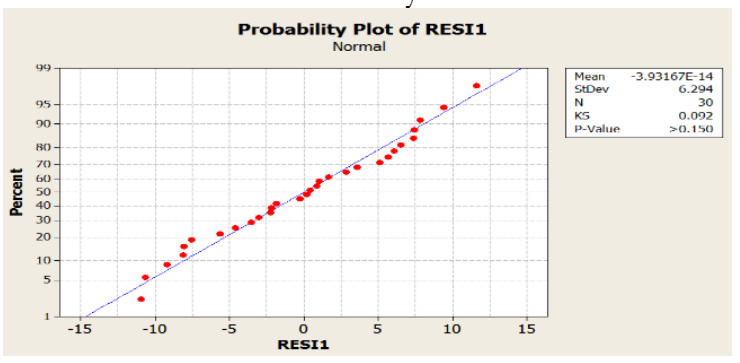

Figure 3. Result of of error normality test using Kolmogorov-Smirnov test

\section{Interpretation:}

Hypothesis:

$H_{0}$ : error spread normally

$H_{1}$ : error does not spread normally

Conclusion:

Normality test using Kolmogorov-Smirnov produced P-value $>0.150$, so there is sufficient evidence to state that $H_{0}$ does not rejected at the real level $5 \%$, it means there is no violation of the normality assumption error.

\section{Result of homogeneity test}

\begin{tabular}{|lrrrrr|}
\hline \multicolumn{7}{|l|}{ Analysis of Variance } \\
Source & DF & SS & MS & F & P \\
Regression & 6 & 101.22 & 16.87 & 1.60 & 0.193 \\
Residual Error & 23 & 243.12 & 10.57 & & \\
Total & 29 & 344.35 & & & \\
\hline
\end{tabular}

Figure 4. Result of homogeneity test using Glejser test
Interpretation:

Hypothesis:

$H_{0}$ : homogeneous error variance

$H_{1}$ : heterogeneous error variance

Conclusion:

Glejser test produced P-value $=0.193$, so there is sufficient evidence to state that the error variance is heterogenic at the real level $5 \%$, in other words, the assumption of homogeneous error variance is fulfilled.

3. Result of detect of error independencies

Runs Test: RESI1
Runs test for RESI1
Runs above and below $K=-3.93167 \mathrm{E}-14$
The observed number of runs $=20$
The expected number of runs $=15.9333$
16 observations above $K, 14$ below
P-value $=0.129$

Figure 5. Result of detect of error independencies Runs Test

Interpretation:

Hypothesis:

$H_{0}$ : independent mutual error

$H_{1}$ : dependent mutual error

Conclusion:

Runs Test produced P-value $=0.129$, is means there is not sufficient evidence yet to state that the error not mutually independent at the real level $5 \%$, so the assumption of error independencies is fulfilled.

4. Result of detect of multicollinearity

\begin{tabular}{|lrrrrr|}
\hline Predictor & Coef & SE Coef & T & P & VIF \\
Constant & 10.79 & 11.59 & 0.93 & 0.362 & \\
X1 & 0.6132 & 0.1610 & 3.81 & 0.001 & 2.667 \\
X2 & -0.0731 & 0.1357 & -0.54 & 0.596 & 1.601 \\
X3 & 0.3203 & 0.1685 & 1.90 & 0.070 & 2.271 \\
X4 & 0.0817 & 0.2215 & 0.37 & 0.715 & 3.078 \\
X5 & 0.0384 & 0.1470 & 0.26 & 0.796 & 1.228 \\
X6 & -0.2171 & 0.1782 & -1.22 & 0.236 & 1.952 \\
\hline
\end{tabular}

Figure 6. Result of detect of multicollinearity

\section{Interpretation:}

The assumption of multicollinearity can be seen through the VIF value on each independent variable. It can be seen that there is no $V I F$ value greater than 9, so it can be concluded that there is no multicollinearity. So this assumption is fulfilled.

Regression analysis $Y$ with $x_{1}$ to $x_{6}$ produce $R^{2}$ value is $73.3 \%$ and there is no violation of 
assumption. Although the model formed is good enough, but not all variables are significant, so it is necessary to create a new model that can explain $Y$ to be better. Some ways are used best subset and stepwise regression. The results of best subset and stepwise regression are as follows:

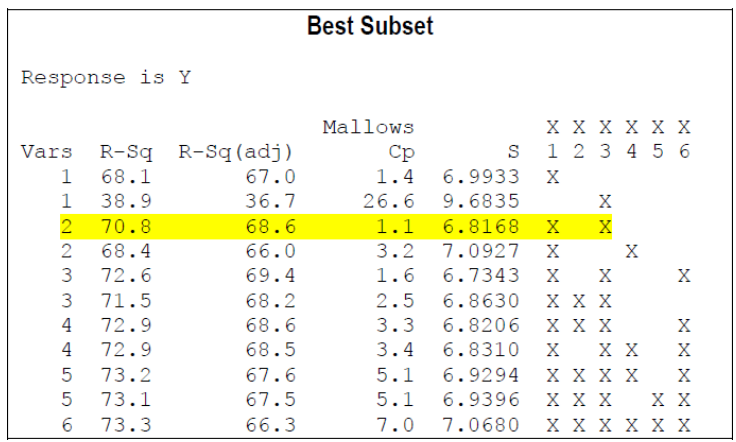

Figure 7. Result of best subset

Interpretation:

The result of best subset concluded that the variables $x_{1}$ and $x_{3}$ were included into the model. When $x_{1}$ and $x_{3}$ are included, the result of $R^{2}$ value model is quiet large compared to the other models, which is $70.8 \%$. Cp Mallow value of 1.1 can also be said to be good because it approaches the number of explanatory variables included into the model that is 2 . The $S$ value of 6.8268 is relatively low when compared by the other models.

\begin{tabular}{|lrr|}
\hline \multicolumn{3}{|c|}{ Stepwise Regression } \\
Alpha-to-Enter: 0.15 & Alpha-to-Remove: 0.15 \\
Response is $\mathrm{Y}$ on 6 & predictors, with N = 30 \\
& & \\
Step & 1 & 2 \\
Constant & 14.376 & 9.871 \\
& & \\
X1 & 0.755 & 0.644 \\
T-Value & 7.74 & 5.43 \\
P-Value & 0.000 & 0.000 \\
& & \\
X3 & & 0.21 \\
T-Value & & 1.57 \\
P-Value & & 0.128 \\
& & \\
S & 6.99 & 6.82 \\
R-Sq & 68.13 & 70.80 \\
R-Sq(adj) & 66.99 & 68.64 \\
Mallows Cp & 1.4 & 1.1 \\
& & \\
\hline
\end{tabular}

Figure 8. Result of stepwise regression

\section{Interpretation:}

Stepwise regression suggested that the variables $x_{1}$ and $x_{3}$ were included into the model.

Base on the results of best subset and stepwise regression, it can be decided to use variables $x_{1}$ and $x_{3}$ into the model. And the result of regression analysis $Y$ with $x_{1}$ and $x_{3}$ as follows:

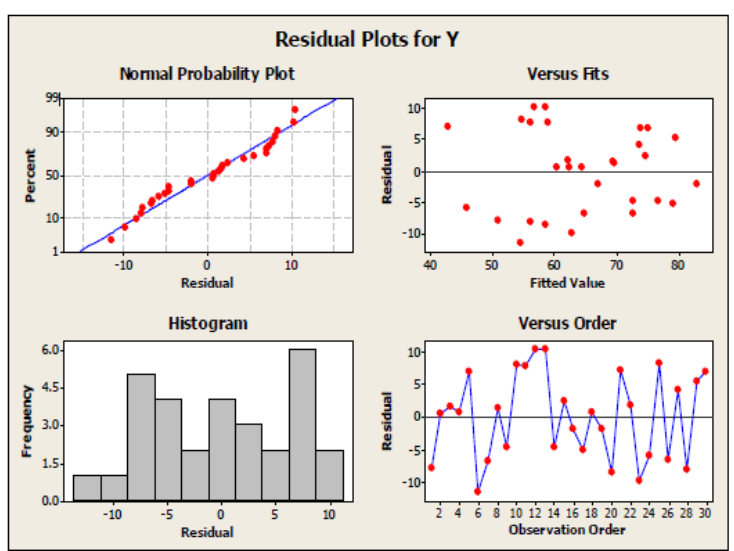

Figure 9. Result of data exploration after best subset and stepwise regression

\section{Interpretation:}

The normal QQ plot shows a normal spread error. Error plot vs fitted value shows a homogeneous errors range, it can be seen from the absence of patterns formed and the same bandwidth. Error plot vs order shown no pattern, so it can be concluded that the errors are mutually independent.

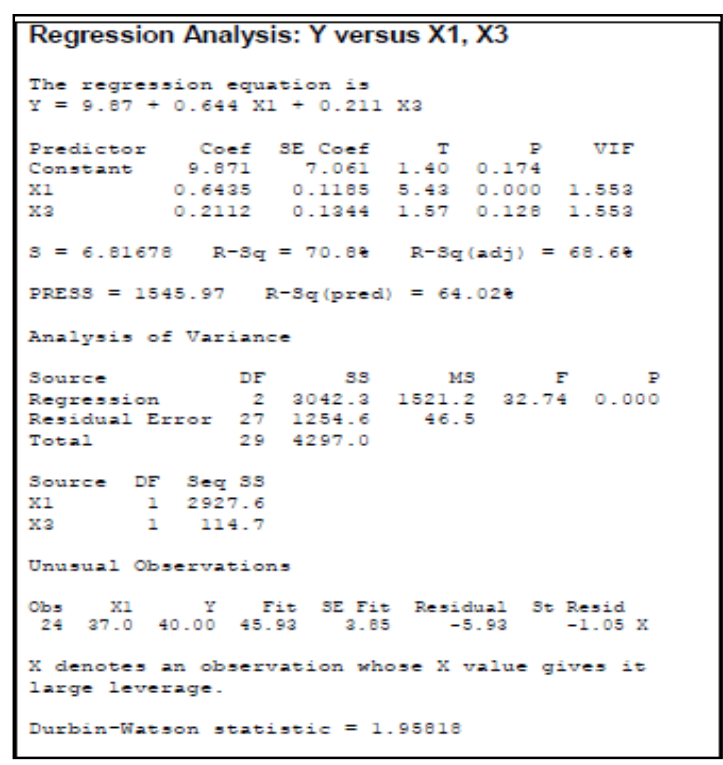

Figure 10. Result of regression analysis after best subset and stepwise regression 


\section{Interpretation:}

The result of regression analysis produces the formula:

$$
Y=9.87+0.644 x_{1}+0.211 x_{2}
$$

F test produced the testing statistics of 32.74 and P-value $=0.000$, so it can be concluded there is sufficient evidence to state that there is at least one explanatory variable that affect $Y$ at the real level $5 \%$. Following the $\mathrm{F}$ test, the test of each explanatory variable using $\mathrm{t}$ test produced $\mathrm{P}$-value $=0.000$ and 0.128 for variables $x_{1}$ and $x_{3}$, so it can be concluded there is sufficient evidence to state that $x_{1}$ affects $Y$ while $x_{3}$ does not affect $Y$ at the real level $5 \%$. The result of $R^{2}$ value is $70.8 \%$, it means that the variance of $Y$ that can be explained by model is $70.8 \%$, while the remaining $29.2 \%$ is explained by variables outside the model. $R^{2}$ and $R^{2}$ pred values on this model are larger than previous model, in other word this model is better. Regression analysis also shows the observed effect on the data, namely the 24th observation. Because this observation is influential, this observation is not removed from the data. Although $x_{3}$ is not significant, but this model is better than when $Y$ is only regressed by $x_{1}$ (it can be seen from best subset).

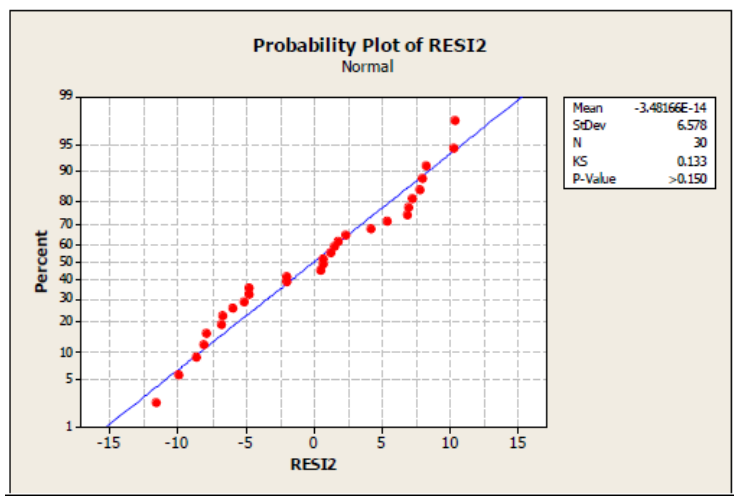

Figure 11. Result of error normality test using Kolmogorov-Smirnov test after best subset and stepwise regression

\section{Interpretation:}

Hypothesis:

$H_{0}$ : error spread normally

$H_{1}$ : error does not spread normally
Conclusion:

P-value $>0.150$ for Kolmogorov-Smirnov test conclude that error spread normally at the real level $5 \%$, so this assumption is fulfilled.

\begin{tabular}{|lrrrrr|}
\hline Analysis of Variance \\
Source & DF & SS & MS & F & P \\
Regression & 1 & 36.850 & 36.850 & 3.78 & 0.062 \\
Residual Error & 28 & 273.033 & 9.751 & & \\
Total & 29 & 309.884 & & & \\
\hline
\end{tabular}

Figure 12. Result of homogeneity using Glejser test after best subset and stepwise regression

\section{Interpretation:}

Hypothesis:

$H_{0}$ : homogeneous error variance

$H_{1}$ : heterogeneous error variance

Conclusion:

P-value $=0.062$ for Glejser test concluded that homogeneous error variance at the real level $5 \%$.

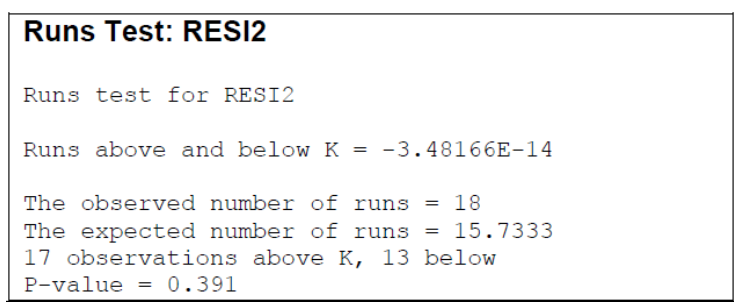

Figure 13. Result of detect of error independencies using Runs Test after Best Subset and Stepwise Regression

Interpretation:

Hypothesis:

$H_{0}$ : independent mutual error

$H_{1}$ : dependent mutual error

Conclusion:

P-value $=0.391$ for Runs Test concluded that between errors does not correlated at the real level $5 \%$.

\begin{tabular}{|lrrrrr|}
\hline Predictor & Coef & SE Coef & T & P & VIF \\
Constant & 9.871 & 7.061 & 1.40 & 0.174 & \\
X1 & 0.6435 & 0.1185 & 5.43 & 0.000 & 1.553 \\
X3 & 0.2112 & 0.1344 & 1.57 & 0.128 & 1.553 \\
\hline
\end{tabular}

Figure 14. Result of detect of multicollinearity after Best Subset and Stepwise Regression

Interpretation:

$V I F$ value on the variables $x_{1}$ and $x_{3}$ are 1.553 and 1.553 indicate that there is no correlation between explanatory variables, so the assumption of the absence of multicollinearity is fulfilled. 


\section{Analysis Result}

Based on the results of multiple linear regression analysis and after proven by the error assumption test, obtained the most optimal model in producing paper thickness in the recycling process using paper recycling machine is

$$
Y=9.87+0.644 x_{1}+0.211 x_{3}
$$

From the model above, it can be seen that the phases that most influence the paper thickness are first phase $\left(x_{1}\right)$ namely destruction phase and $\left(x_{3}\right)$ namely press phase.

\section{CONCLUSION}

The phases that influence the paper thickness on the recycling process using paper recycling machine are first phase $\left(\boldsymbol{x}_{\mathbf{1}}\right)$ namely destruction phase and third phase $\left(\boldsymbol{x}_{\mathbf{3}}\right)$ namely press phase. This is reinforced by the data obtained that has fulfilled the error assumption test. So that in producing optimal recycled paper thickness, the phase that needs attention are destruction phase and press phase.

\section{REFERENCES}

Asmatulu, R., \& Asmatulu, E. (2011). Importance of recycling education: a curriculum development at WSU. Journal of Material Cycles and Waste Management, 13(2), 131.

Djami, R. (2014). Metode PCR-TOPSIS untuk Optimasi Taguchi Multirespon. Institut Teknologi Sepuluh Nopember.

Effendi, E., Mursilah, M., \& Mujiono, M. (2018). Korelasi Tingkat Perhatian Orang Tua dan Kemandirian Belajar dengan Prestasi Belajar Siswa. Titian Ilmu: Jurnal Ilmiah Multi Sciences, 10(1), 17-23. https://doi.org/10.30599/jti.v10i1.131

Faraz, A., Biermann, D., \& Weinert, K. (2009). Cutting edge rounding: An innovative tool wear criterion in drilling CFRP composite laminates. International Journal of Machine Tools and Manufacture, 49(15), 1185-1196.
Goddard, J., Tavakoli, M., \& Wilson, J. O. S. (2005). Determinants of profitability in European manufacturing and services: evidence from a dynamic panel model. Applied Financial Economics, 15(18), 1269_ 1282.

Hongxun, C., Weiwei, L., Wen, J., Peiru, W., \& Bing, Z. (2011). Development of low specific-speed centrifugal pump impellers based on flow control technique. Chinese Journal of Drainage and Irrigation Machinery Engineering, 6(9), 466-470.

Irianto, A. (2004). Statistik konsep dasar dan aplikasinya. Jakarta: Kencana.

Johnson, R. A., \& Bhattacharyya, G. . (2010). Statistics, Principles and Methods (6th ed.). New York: John Wiley \& Sons, Inc.

Kusuma, T. W. N., \& Puspita, D. (2016). Aplikasi Komputer dan Pengolahan Data: Pengantar Statistik Industri. Malang: UB Press.

Kutner, M. H., Nachtsheim, C. J., Neter, J., \& Li, W. (2005). Applied linear statistical models (4th ed.). New York: McGraw-Hill Irwin New York.

Montgomery, D. C., Peck, E. A., \& Vining, G. G. (2012). Introduction to linear regression analysis (5th ed.). New York: John Wiley \& Sons.

Rahmasari, F. (2017). Optimasi Multirespon Metode Tagucbi Menggunakan PCA-TOPSIS dan Metode Vikor. Institut Pertanian Bogor.

SATHEESH, M., \& EDWIN RAJA DHAS, J. (2013). MULTI OBJECTIVE OPTIMIZATION OF FLUX CORED ARC WELD PARAMETERS USING FUZZY BASED DESIRABILITY FUNCTION. IRANLAN JOURNAL OF SCIENCE AND TECHNOLOGY TRANSACTION B- ENGINEERING, 
37(M2

(MECHANICAL

ENGINEERING)), 175-187.

Soejanto, I. (2009). Desain eksperimen dengan metode taguchi. Yogyakarta: Graha Ilmu.

Tan, X., \& Engeda, A. (2016). Performance of centrifugal pumps running in reverse as turbine: Part II - systematic speci fi c speed and speci fi c diameter based performance prediction. Renewable Energy, 99, 188-197.

Widiyawati, W., \& Setiawan, S. (2015). Analisis Faktor-Faktor yang Mempengaruhi Tingkat Produksi Padi dan Jagung di Kabupaten Lamongan. Jurnal Sains Dan Seni ITS, 4(1), D103-D108.

Yafie, E., Kustiawan, U., \& Seken, I. M. (2018). Pelatihan Pembuatan Benda Cinderamata dari Bahan Kertas Daur Ulang untuk Kegiatan Kewirausahaan Mahasiswa dan Guru Alumni. Abdimas Pedagogi: Jurnal Ilmiah Pengabdian Kepada Masyarakat, 1(2), 122-127.

Zahra, F., \& Damanhuri, T. P. (2011). Kajian Komposisi, Karakteristik, dan Potensi Daur Ulang Sampah di TPA Cipayung, Depok. Jurnal Teknik Lingkungan, 17(1), 59-69.

https://doi.org/http://dx.doi.org/10.561

4\%2Fjtl.2011.17.1.6 